\title{
Role of Epidural Injections to Prevent Surgical Intervention in Patients with Chronic Sciatica: A Systematic Review and Meta-Analysis
}

\author{
Adnan Bashir Bhatti ${ }^{1}$, Sunny Kim ${ }^{2}$ \\ 1. Medical Director of Clinical Research, Spine Surgery, Tristate Brain and Spine Institute, United States \\ 2. Spine Surgery, Tristate Brain and Spine Institute
}

$\square$ Corresponding author: Adnan Bashir Bhatti, dr.adnanbashir@gmail.com Disclosures can be found in Additional Information at the end of the article

\section{Abstract}

Objective: The aim of this study is to evaluate the efficacy of the different types of epidural injections (EI) to prevent surgical intervention in patients suffering from chronic sciatica due to lumbar disc herniation (LDH).

Material and Methods: Studies were identified by searching PubMed, MEDLINE, and Google Scholar to retrieve all available relevant articles. Lists of references of several systematic reviews were also used for scanning further references. Publications from the past ten years (2006-2016) were considered, and all studies selected were in the English language only. The studies employed specified the use of EI to treat sciatica caused by LDH. A total of 19 papers meeting the eligibility criteria (mentioned below) were included in this study. The pain scores, functional disability scores, and surgical rates from these studies were considered, and metaanalysis was performed.

Outcome measures: Pain scores, functional disability scores, and surgical rates were assessed from the included studies. The Numeric Rating Scale (NRS) and Visual Analogue Scale (VAS) have been the most commonly used baseline scales for pain evaluation followed by the Verbal Numerical Rating Scale (VNRS) and Japanese Orthopedic Association (JOA). The Oswestry Disability Index (ODI) and Roland Morris Disability Questionnaire (RMDQ) scales were used for the functional disability scoring system in the literature.

Results: Significant improvement in the pain scores and functional disability scores were observed. Additionally, greater than $80 \%$ of the patients suffering from chronic sciatica caused by LDH could successfully prevent surgical intervention after EI treatment with or without steroids.

Received 07/25/2016 Review began 07/28/2016 Review ended 07/28/2016 Published 08/04/2016

\section{(C) Copyright 2016}

Bhatti et al. This is an open access article distributed under the terms of the Creative Commons Attribution License CC-BY 3.0., which permits unrestricted use, distribution, and reproduction in any medium, provided the original author and source are credited.
Categories: Neurology, Neurosurgery, Orthopedics Keywords: sciatica, chronic back pain, epidural injection, disc herniation, lumbar radiculopathy 


\section{Introduction}

Medical literature refers to sciatica as a lumbosacral radicular syndrome, lumbar radiculopathy, nerve root pain, and nerve root entrapment/irritation. It is characterized by pain radiating from the back into the leg [1-3]. It is a common and debilitating symptom rather than a specific diagnosis. It may be caused by lumbar disc herniation (LDH), lumbar canal or foraminal stenosis, and or inflammatory processes around the nerve root [4]. Among all the causes, LDH is the most common cause of sciatica leading to surgical interventions [5] and was first reported by Mixter and Barr in 1934. According to some estimates, the prevalence of sciatica caused by LDH approaches 9.8 per 1,000 cases, of which $3.7 \%$ are in women and $5.1 \%$ in men [6]. In the general population, the sciatica is reported in $1-2 \%$ of these cases; LDH has been reported to occur in $90 \%$ [7].

There is a general agreement that sciatica due to LDH is frequently a self-limited condition, and therefore, most of these patients will improve within weeks to months without any medical intervention. A few patients may require conservative management such as rest, analgesics, traction, medication, physical therapy, or a structured exercise program. Nevertheless, for the patients who are refractory to four to six months of conservative management or their pain is progressive under the conservative management, in such patients surgical intervention is recommended [8]. The primary aim of any surgical intervention is to provide rapid relief from pain and functional disability [5]. Surgical intervention is rapidly effective, but it is a costly procedure and associated with several post-operative complications, including but not limited to chronic pain and persistent disability [9]. Moreover, long-term outcomes of conservative management have been reported to be better than surgical intervention in several studies [1011]. Additionally, surgical intervention is not available for everyone who is symptomatic and may lead to failure in approximately $25 \%$ of carefully selected cases [12].

Sciatica occurs most commonly due to herniation of a lumbar intervertebral disc, resulting in an inflammatory response around the nerve root. This inflammatory response rather than mechanical compression is the primary cause of the radicular pain. Therefore, antiinflammatory drugs are used to reduce pain by reducing the inflammation around the nerve [2]. Several minimally invasive (MI) anti-inflammatory treatments such as segmental epidural steroid injections (ESI), selective nerve root blocks, disc decompression using laser energy (laser discectomy), radiofrequency coblation (nucleoplasty), intradiscal oxygen-ozone (O2-O3) injection for treating disc-related radiculopathy as an alternatives to surgical intervention [9] have been devised.

Among various modalities applied in the management of painful conditions of the spine, EI is one of the most commonly utilized non-surgical interventions [13]. All the procedures mentioned above are either associated with side effects or lesser effectiveness [9]. Thus, EI seems to be the best non-surgical alternative treatment option available for severe cases of sciatica. The use of EI for the management of lower back pain and sciatica was initiated in 1900 in Paris by Jean Sicard and Fernand Cathelin [14]. At present, EIs are administered in the lumbar spine by three different approaches namely caudal, interlaminar, and transforaminal [13]. Different types of steroids have been used in these injections including triamcinolone, methylprednisolone, betamethasone, and dexamethasone [14]. These EIs are aimed at providing analgesia for a variable duration during which the patient can go for rehabilitation exercises [15]. It has been hypothesized that EI is a better alternative treatment option than surgical intervention for patients who do not wish to undergo more invasive procedures. It is evidenced by the fact that many chronic back pain patients visit the pain management clinics every couple of weeks to get repeated epidural injections [14].

Various systematic reviews over time evaluated the efficacy of EI by comparing its outcomes with conservative management. Nevertheless, to the best of our knowledge, there has been no 


\section{Cureus}

systematic review and meta-analysis of the potential role of EI in preventing surgical intervention. This study assessed the possible role of EI in preventing surgical intervention based on the outcome measures assessment after EI treatment in the past ten years from 2006 to 2016.

\section{Materials And Methods}

In this study, we aimed to update the literature on the potential role of EI in preventing surgical intervention based on outcome measures assessment after treatment with EI for sciatica or radiculitis caused by LDH. To accomplish this purpose, we searched databases like MEDLINE, PubMed Central, Google Scholar, and included papers published between 2006 to 2016. We reviewed literature in the English language only. Lists of references of several systematic reviews were also used for scanning further references.

\section{Data extraction}

Combinations of the following keywords were used for data extraction: lumbar disc herniation, lumbosciatic pain, radicular pain, radiculitis, sciatica, epidural injection, epidural steroid, epidural perineural injection, interlaminar epidural, intra-articular corticosteroid, transforaminal injection, caudal epidural injection.

The result was the identification of 169 relevant papers, 63 of which were found to be published in the past 10 years. Scanning titles, we found 27 of the 63 papers relevant to our study based on the selection criteria mentioned later in the text. A lack of included information led to the exclusion of 2 papers. Further, 6 more papers were excluded due to the absence of surgical rate data, or sciatica was associated with the causes other than LDH. Figure 1 summarizes the results of the literature search and inclusion steps of the studies.

Keywords based, search of literature: 169 potential publications

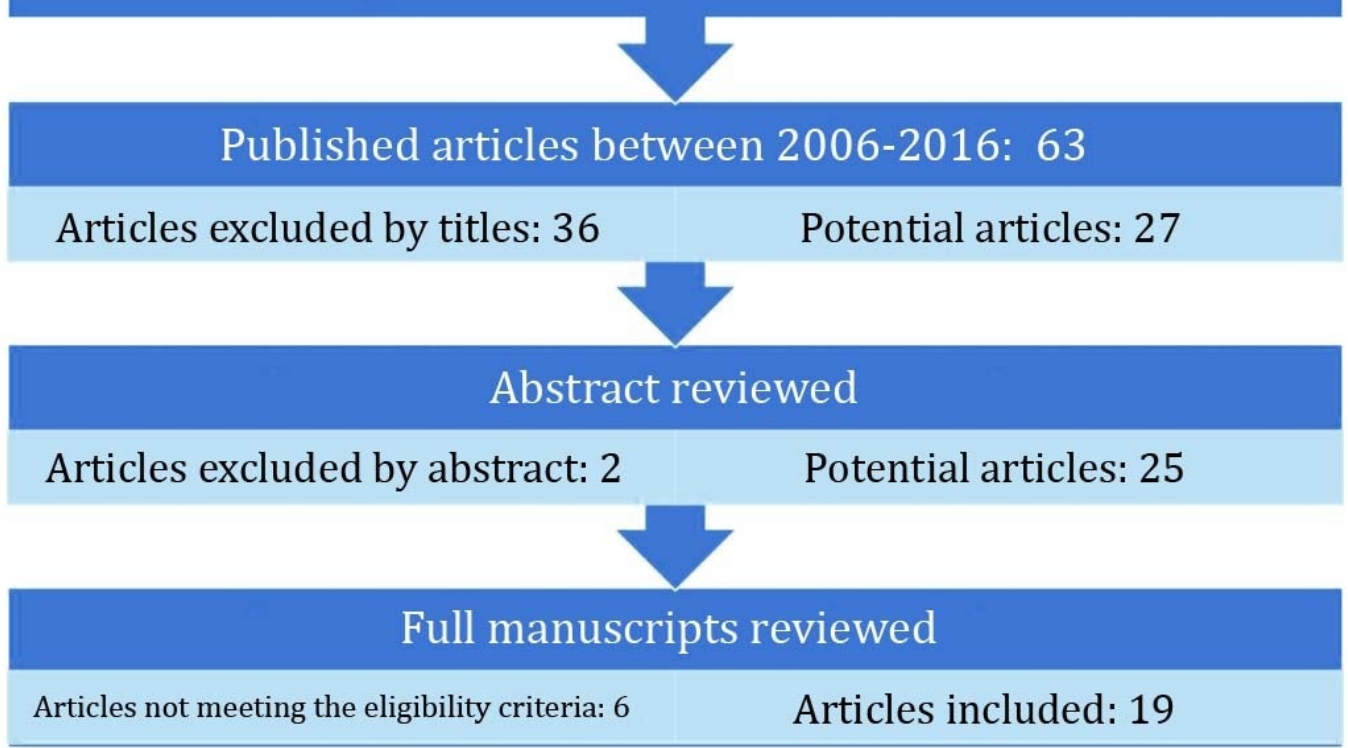

FIGURE 1: Flow Chart of the Included Studies.

\section{Selection criteria}




\section{Cureus}

\section{Types of Studies}

Randomized controlled trials (RCT), prospective observational studies, retrospective studies, double-blind clinical trials, and full-text journal articles published in peer-reviewed journals were included in this study. Table 1 summarizes the details of the included studies.

\begin{tabular}{|c|c|c|c|c|c|c|c|c|c|}
\hline \multirow{2}{*}{ Study } & \multirow{2}{*}{ Study Design } & \multirow{2}{*}{ Injection } & \multirow{2}{*}{$\begin{array}{l}\text { Mean } \\
\text { Age }\end{array}$} & \multirow{2}{*}{$\begin{array}{l}\text { Sample } \\
\text { Size }\end{array}$} & \multicolumn{2}{|c|}{ Gender (\%) } & \multirow{2}{*}{ Diagnosis } & \multirow{2}{*}{$\begin{array}{l}\text { Pain } \\
\text { Duration } \\
\text { (Weeks) }\end{array}$} & \multirow{2}{*}{$\begin{array}{l}\text { Maximum } \\
\text { FU } \\
\text { (Months) }\end{array}$} \\
\hline & & & & & Females & Males & & & \\
\hline $\begin{array}{l}\text { Sayegh } \\
\text { (2009) [25] }\end{array}$ & $\begin{array}{l}\text { Prospective, } \\
\text { randomized, double- } \\
\text { blind clinical trial }\end{array}$ & steroid & 49.12 & 183 & $32.78 \%$ & $67.23 \%$ & pain and sciatica & $>4$ & 12 \\
\hline $\begin{array}{l}\text { Ghahreman } \\
\text { (2010) [3] }\end{array}$ & $\begin{array}{l}\text { Prospective, } \\
\text { randomized study }\end{array}$ & $\begin{array}{l}\text { TFEI with } \\
\text { steroid }\end{array}$ & 49.5 & 150 & $40.66 \%$ & $59.30 \%$ & $\begin{array}{l}\text { Lumbar disc } \\
\text { herniation }\end{array}$ & 12 & 12 \\
\hline $\begin{array}{l}\text { Manchikanti } \\
\text { (2014 A) } \\
{[17]}\end{array}$ & $\begin{array}{l}\text { Randomized, } \\
\text { controlled, double- } \\
\text { blind, active control } \\
\text { trial }\end{array}$ & $\begin{array}{l}\text { TFEl with or } \\
\text { without } \\
\text { steroids }\end{array}$ & 42.85 & 120 & $50 \%$ & $50 \%$ & $\begin{array}{l}\text { Lumbar disc } \\
\text { herniation and } \\
\text { radiculitis }\end{array}$ & 24 & 24 \\
\hline $\begin{array}{l}\text { Manchikanti } \\
\text { (2014 B) } \\
{[12]}\end{array}$ & $\begin{array}{l}\text { Randomized, } \\
\text { controlled, double- } \\
\text { blind, active control } \\
\text { trial. }\end{array}$ & $\begin{array}{l}\text { LIEl with or } \\
\text { without } \\
\text { steroids }\end{array}$ & 44.5 & 120 & $69.20 \%$ & $30.80 \%$ & $\begin{array}{l}\text { Lumbar disc } \\
\text { herniation and } \\
\text { radiculitis }\end{array}$ & 24 & 24 \\
\hline $\begin{array}{l}\text { Manchikanti } \\
\text { (2011) [21] }\end{array}$ & $\begin{array}{l}\text { Randomized, } \\
\text { controlled, double-blind } \\
\text { trial }\end{array}$ & $\begin{array}{l}\text { CEl without } \\
\text { steroid }\end{array}$ & 45.85 & 120 & $65 \%$ & $35 \%$ & $\begin{array}{l}\text { Lumbar disc } \\
\text { herniation and } \\
\text { radiculitis }\end{array}$ & 24 & 12 \\
\hline $\begin{array}{l}\text { Manson } \\
\text { (2013) [18] }\end{array}$ & Retrospective & steroids & 45.8 & 91 & $41.75 \%$ & $58.24 \%$ & $\begin{array}{l}\text { Lumbar disc } \\
\text { herniation and/or } \\
\text { radiculopathy }\end{array}$ & 6 & 26.6 \\
\hline $\begin{array}{l}\text { Manchikanti } \\
\text { (2008) [26] }\end{array}$ & $\begin{array}{l}\text { A randomized, double- } \\
\text { blind, equivalence trial. }\end{array}$ & $\begin{array}{l}\text { CEl without } \\
\text { steroid }\end{array}$ & 47.05 & 84 & $66.60 \%$ & $33.33 \%$ & $\begin{array}{l}\text { Lumbar disc } \\
\text { herniation and } \\
\text { radiculitis }\end{array}$ & 24 & 12 \\
\hline $\begin{array}{l}\text { Owlia (2007) } \\
\text { [28] }\end{array}$ & Comparative study & $\begin{array}{l}\text { LEl with } \\
\text { steroid }\end{array}$ & 38.2 & 84 & $57.14 \%$ & $42.80 \%$ & $\begin{array}{l}\text { Lumbar radicular } \\
\text { pain }\end{array}$ & $>2$ & 3 \\
\hline $\begin{array}{l}\text { Kennedy } \\
\text { (2014) [1] }\end{array}$ & $\begin{array}{l}\text { Multicenter, double- } \\
\text { blind, prospective, } \\
\text { randomized trial }\end{array}$ & $\begin{array}{l}\text { IFEl with } \\
\text { steroids }\end{array}$ & 35.75 & 78 & $34.61 \%$ & $65.38 \%$ & radicular pain & 8 & 6 \\
\hline $\begin{array}{l}\text { Manchikanti } \\
\text { (2010) [23] }\end{array}$ & $\begin{array}{l}\text { Randomized, double- } \\
\text { blind, controlled trial }\end{array}$ & $\begin{array}{l}\text { LIEl with } \\
\text { injections }\end{array}$ & 41.95 & 70 & $65.71 \%$ & $34.26 \%$ & $\begin{array}{l}\text { Lumbar radicular } \\
\text { pain }\end{array}$ & 24 & 12 \\
\hline $\begin{array}{l}\text { Helvoirt } \\
\text { (2014) [16] }\end{array}$ & $\begin{array}{l}\text { Prospective cohort } \\
\text { study }\end{array}$ & $\begin{array}{l}\text { TFEI with } \\
\text { steroids }\end{array}$ & $4 / .3$ & 69 & $50.70 \%$ & $49.30 \%$ & $\begin{array}{l}\text { Lumbar disc } \\
\text { herniation }\end{array}$ & 20 & 12 \\
\hline Rados & Randomized & FEI \& LIE & 49.2 & 64 & $35.90 \%$ & $64.10 \%$ & $\begin{array}{l}\text { Chronic lumbar } \\
\text { radicular pain }\end{array}$ & 12 & 6 \\
\hline
\end{tabular}




\section{Cureus}

\begin{tabular}{|c|c|c|c|c|c|c|c|c|c|}
\hline (2011) [22] & prospective study & with steroid & & & & & $\begin{array}{l}\text { caused by } \\
\text { herniated disc }\end{array}$ & & \\
\hline $\begin{array}{l}\text { Spijker- } \\
\text { Huiges } \\
\text { (2014) [2] }\end{array}$ & $\begin{array}{l}\text { Randomized controlled } \\
\text { trial }\end{array}$ & $\begin{array}{l}\text { TFEI with } \\
\text { steroids }\end{array}$ & 43.7 & 63 & $47.61 \%$ & $52.38 \%$ & $\begin{array}{l}\text { Lumbosacral } \\
\text { radicular } \\
\text { syndrome }\end{array}$ & $2-4$ & 13 \\
\hline $\begin{array}{l}\text { Gomez } \\
(2007)[27]\end{array}$ & Retrospective & $\begin{array}{l}\text { LIEI with } \\
\text { steroid }\end{array}$ & 47 & 60 & $50 \%$ & $50 \%$ & $\begin{array}{l}\text { Lumbosciatic } \\
\text { pain }\end{array}$ & $24-48$ & 6 \\
\hline $\begin{array}{l}\text { Baral (2011) } \\
{[20]}\end{array}$ & $\begin{array}{l}\text { Prospective } \\
\text { observational study }\end{array}$ & $\begin{array}{l}\text { TFEI with } \\
\text { steroid }\end{array}$ & 41.04 & 50 & $48 \%$ & $52 \%$ & $\begin{array}{l}\text { Lumbar disc } \\
\text { herniation }\end{array}$ & NA & 6 \\
\hline $\begin{array}{l}\text { Kawu (2012) } \\
\text { [19] }\end{array}$ & $\begin{array}{l}\text { Prospective-controlled } \\
\text { observational study }\end{array}$ & $\begin{array}{l}\text { TFEI \& LIEI } \\
\text { with steroids }\end{array}$ & 47.6 & 49 & NA & NA & $\begin{array}{l}\text { Lumbar disc } \\
\text { herniation }\end{array}$ & 31.2 & 6 \\
\hline $\begin{array}{l}\text { Schaufele } \\
\text { (2006) [29] }\end{array}$ & Retrospective & $\begin{array}{l}\text { LIEI Versus } \\
\text { TFEI without } \\
\text { steroid }\end{array}$ & NA & 40 & NA & NA & $\begin{array}{l}\text { Lumbar } \\
\text { intravertebral disc } \\
\text { herniation }\end{array}$ & $2-48$ & 12 \\
\hline $\begin{array}{l}\text { Laiq (2009) } \\
\text { [24] }\end{array}$ & $\begin{array}{l}\text { Quasi-experimental } \\
\text { study }\end{array}$ & $\begin{array}{l}\text { LEI with } \\
\text { steroid }\end{array}$ & 40.5 & 25 & $68 \%$ & $32 \%$ & $\begin{array}{l}\text { Lumbar radicular } \\
\text { pain }\end{array}$ & 2 & 6 \\
\hline $\begin{array}{l}\text { Yang (2006) } \\
\text { [30] }\end{array}$ & Prospective & $\begin{array}{l}\text { TFEl with } \\
\text { steroid }\end{array}$ & 50 & 19 & $42.10 \%$ & $57.89 \%$ & $\begin{array}{l}\text { Sciatica with } \\
\text { unilateral } \\
\text { symptoms }\end{array}$ & $8-96$ & 24 \\
\hline
\end{tabular}

\section{TABLE 1: Literature Map}

TFEI = Transforaminal epidural injections; ILEI = Interlaminar lumbar epidural injections; CEI = Caudal epidural injections; LEI = Lumbar epidural injections; NA = Not available; FU = Follow-up.

Types of Participants

Patients who had sciatica with the pain duration of more than 2 weeks secondary to LDH were included in the study.

Types of Epidural Injection Approaches

Three different approaches have been used in the literature: lumbar transforaminal epidural injection (TEI), lumbar interlaminar epidural injection (IEI), and caudal epidural injections (CEI).

\section{Types of Outcome Measures}

All possible available outcome measures such as pain scores, functional disability scores, and surgical rates were assessed from the literature, and meta-analysis was performed. The Numeric Rating Scale (NRS) and Visual Analogue Scale (VAS) were observed to be the most commonly used scales for pain evaluations followed by the Verbal Numerical Rating Scale (VNRS) and Japanese Orthopedic Association (JOA). The Oswestry Disability Index (ODI), Roland Morris Disability Questionnaire (RMDQ), and International Classification of Impairments, Disabilities, and Handicaps (ICIDH) by WHO Grade score were considered for the functional disability 


\section{Cureus}

scoring system in the literature.

\section{Results}

The average patient sample size was 81 in the included studies. Females were slightly more affected with sciatica secondary to LDH than males, with an average percentage of $51 \%$ and $49 \%$, respectively. All patients were adults with a relatively young age; the mean age was $45 \pm 4$ years. Follow-up time reported in the studies ranged from three months to two years.

\section{Pain score}

Pain score has been assessed in 16 studies [1-2, 12, 16-17, 19-24, 26-30]. The NRS was used in 7 studies [1-2, 12, 17, 21, 23, 26], VAS used in 7 studies [16, 19-20, 22, 24, 27-28], and VNRS and JOA used in the remaining 2 studies [29-30].

In those studies where pain assessment was documented using the NRS scale, the mean baseline scores pre-treatment in two studies [2, 12] were observed to be 7.7-8.25, which reduced post-injection to $1.3-4.1$, respectively, at the last follow-up; that is a $50-83 \%$ improvement from the pre-injection state, as shown in Table 2.

\begin{tabular}{|c|c|c|c|}
\hline Study & Baseline & Last Follow-up & $\%$ \\
\hline \multicolumn{4}{|l|}{ Studies reported NRS } \\
\hline Spijker-Huiges (2014) [2] & 7.7 & 1.3 & 83 \\
\hline Kennedy (2014) [1] & 6.9 & 1.31 & 81 \\
\hline Manchikanti (2010) [23] & 8 & 3.6 & 55 \\
\hline Manchikanti (2008) [26] & 7.95 & 3.6 & 55 \\
\hline Manchikanti (2011) [21] & 7.95 & 3.8 & 52 \\
\hline Manchikanti (2014 A) [17] & 8.1 & 3.9 & 52 \\
\hline Manchikanti (2014 B) [12] & 8.25 & 4.1 & 50 \\
\hline \multicolumn{4}{|l|}{ Studies reported VAS score } \\
\hline Helvoirt (2014) [16] & 52.3 & 8.99 & 83 \\
\hline Kawu (2012) [19] & 77.6 & 39.6 & 49 \\
\hline Baral (2011) [20] & 6.98 & 3.68 & 47 \\
\hline Rados (2011) [22] & 7.04 & 3.9 & 45 \\
\hline \multirow[t]{5}{*}{ Laiq (2009) [24] } & 6 & 6 & 0 \\
\hline & $\begin{array}{l}\text { VAS } 10 \text { (very severe pain) } \\
\text { Patients }(30 \%)\end{array}$ & $\begin{array}{l}\text { VAS } 10 \text { (very severe pain) } \\
\text { Patients }(6.7 \%)\end{array}$ & \\
\hline & VAS 6-9 (severe pain) & VAS 6-9 (severe pain) & \\
\hline & Patients (50\%\%) & Patients (21.7\%\%) & \\
\hline & VAS 3-5 (moderate pain) & VAS 3-5 (moderate pain) & \\
\hline
\end{tabular}




\section{Cureus}

\author{
Gomez (2007) [27] Patients (20\%) \\ VAS 1-2 (mild pain) \\ Patients ( $0 \%)$ \\ VAS 0 (no pain) \\ Patients $(0 \%)$
}

Owlia (2007) [28]

NA

6.6

14.26

Studies reported VNRS

Scahufele (2006) [29]
Study reported JOA

Yang (2006) [30]
Patients (11.7\%)

NA

VAS 1-2 (mild pain)

Patients (25\%)

VAS 0 (no pain)

Patients (35\%)

NA

58

4.55

31

\section{TABLE 2: Pain Scores}

NRS = Numeric Rating Scale; VAS = Visual Analogue Scale; VNRS = Verbal Numerical Rating Scale; JOA = Japanese Orthopedic Association (JOA).

Further, among 7 studies reporting the VAS scale, the study by Helvoirt et al., (2014) [16] mean baseline value was 52.3 that reduced to mean value of 8.99 at the last follow-up, which is an 83\% improvement in the pain score. In another study of Kawu et al., (2012) [19] mean baseline value of 77.6 pre-treatment was reduced to 39.6, approximately a 50\% improvement. Further, 3 studies reported mean baseline VAS scores were greater than 6 [20, 22, 24]; among these, in Baral et al., [20] the value reduced to 3.68, and in Rados et al., (2011) [22] the value reduced to 3.9. However, in the remaining 1 study by Laiq et al., (2009) [24], no statistically significant improvement was observed, but $68 \%$ of the patients reported pain relief. In another study by Gomez et al., [27] baseline VAS score was $\geqslant 6$ in $80 \%$ patients, and none of the patients had a VAS score of 0-2 at the baseline. At the last follow-up, greater than $70 \%$ of the patients achieved a VAS score between $0-5$ with $60 \%$ of the patients having a VAS score of $0-2$, representing a significant improvement post-EI treatment. Owlia et al., (2007) [28] also reported improvement of $65.4 \%, 75 \%$, and $58.3 \%$ at the follow-up of two weeks, one month, and three months, respectively.

Further, in 2 studies [29-30] reporting VNRS and JOA scores for pain evaluation, a statistically significant improvement was observed. In 1 study reporting a VNRS score, a 31\% improvement was observed [29]. In the other study by Yang et al., (2006) [30] significant improvement of the JOA score from 14.26 at baseline to 23.38 at the last follow-up was reported.

Thus, the literature published in the past ten years has reported a significant improvement in the pain scores, and no study was found to be reporting a worsening of the pain score. The details about the pain scores are given in Table 2.

\section{Functional disability score}

There was a total of 13 studies in which four different types of functional disability scoring systems were reported. The ODI scores are reported in 9 studies [12, 17, 19-23, 25-26], RMDQ in 2 studies [2, 16], International Classification of Impairments, Disabilities, and Handicaps 
(ICIDH) by WHO Grade score in 1 study [27], and JOA score in 1 study [30]. In all of these studies, a significant improvement after EI was observed.

Among 9 studies reporting ODI scores for functional disability, 5 considered $\geqslant 50 \%$ reduction in ODI as a significant clinical improvement $[1,12,17,21,23], 1$ considered $\geqslant 40 \%$ reduction as a significant clinical improvement [26], and 1 considered $>10$ points or $\geqslant 20 \%$ change as a significant clinical improvement [20].

Kennedy et al., (2014) [1] reported a baseline ODI measure of "severe disability" at the score range 40-60, which reduced to "minimal disability" at the range of 0-20 at the last follow-up. In 5 studies by Manchikanti et al., [12, 17, 21, 23, 26] the ODI mean baseline value of 29 reduced to 14 at the last follow-up, indicating a $>50 \%$ improvement in the functional disability score. Further, greater than 75\% improvement was reported in two groups by Sayegh et al (2009) [25]. In two studies by Kawu et al., (2012) [19] and Baral et al., (2011) [20] the mean baseline ODI of $>60$ was reported, which moved to 32 and 35.68 , respectively, at the last follow-up, which is greater than a $40 \%$ improvement. Rados et al., [22] reported only a $26 \%$ improvement post-EI.

Further, among 2 studies $[2,16]$ reporting the RMDQ scoring system, the mean baseline scores of 12.2-16.5 moved significantly to 3.3-2.3 at the last follow-up, which indicates an 80\% improvement.

A study by Gomez et al., (2007) [27] reported a grading score system by WHO; Grades 2 \& 3 and Grade 1 had 65\% and 35\% of patients, respectively; no patient was in Grade 0. Post-injection average of $76 \%$ of the patients moved to Grade $0-1$ at the last follow-up, and $50 \%$ were in Grade 0 . The study by Yang et al., (2006) [30] also reported significant improvement in the JOA score of daily activity at the last follow-up.

Thus, in the literature published in the past ten years, significant improvement in functional disability scores post-injection has been observed. The details about the functional disability scores are given in Table 3. 


\section{Cureus}

\section{Study}

Studies reported ODI

Baral (2011) [20]

Kawu (2012) [19]

Rados (2011) [22]

Sayegh (2009) [25]

Manchikanti (2014 A) [17]

Manchikanti (2014 B) [12]

Manchikanti (2011) [21]

Manchikanti (2010) [23]

Manchikanti (2008) [26]

Studies reported RMDQ

Helvoirt (2014) [16]

Spijker-Huiges (2014) [2]

Studies reported ICIDH by WHO

Gomez (2007) [27]

Yang (2006) [30]
Mean Baseline

Follow-up

\% Improvement

60.86

61

$\sim 54$

38.5

29.95

28.95

28.55

29.35

28.55

12.2

16.5

3.3

2.3

\section{Grade 3}

(11.7\%)

Grade 2

(53.3\%)

\section{Grade 1}

(35\%)

Grade 0

(0\%)

$7.44 \pm 2.16$

\section{Grade 3}

$3.3 \%$

Grade 2

$20 \%$

Grade 1

26.7

Grade 0

$50 \%$
73

86

41

48

26

77

51

50

50

52

53

NA

\section{TABLE 3: Functional Disability Scores}

ODI = Oswestry Disability Index; RMDQ = Roland Morris Disability Questionnaire; ICIDH = International Classification of Impairments, Disabilities, and Handicaps; JOA = Japanese Orthopedic Association.

\section{Surgical rate}

Among 19 studies, the surgical rate has been reported in 9 studies [1, 16, 18-20, 24-25, 29-30]. Based on the literature review of past ten years, we found that surgical rate post-EI treatment 


\section{Cureus}

was between $13 \%$ and $21 \%$ in 7 studies [1, 16, 20, 24-25, 29-30], depicting that greater than $78 \%$ of the patients were able to prevent surgical intervention. Additionally, in 1 study [19], the surgical rate was found to be only $7.05 \%$ post-EI treatment, which showed a greater than $90 \%$ reduction in surgical rate. The highest surgical rate was $44 \%$ in one study [18], and thus only $56 \%$ of the patients could prevent surgical intervention. Overall, on an average of $80 \%$, patients were able to avoid surgical intervention with the help of EI treatment. The details about the surgical rates are given in Table 4.

\begin{tabular}{|c|c|c|}
\hline Study & Average Surgical Rate After El & Average Non-Surgical Rate After EI \\
\hline Kawu (2012) [19] & $7.05 \%$ & $92.95 \%$ \\
\hline Baral (2011) [20] & $13.00 \%$ & $87.00 \%$ \\
\hline Yang (2006) [30] & $15.80 \%$ & $84.20 \%$ \\
\hline Kennedy (2014) [1] & $16.75 \%$ & $83.25 \%$ \\
\hline Schaufele (2006) [29] & $17.50 \%$ & $82.50 \%$ \\
\hline Sayegh (2009) [25] & $17.50 \%$ & $82.50 \%$ \\
\hline Laiq (2009) [24] & $20.00 \%$ & $80.00 \%$ \\
\hline Helvoirt (2014) [16] & $21.70 \%$ & $78.30 \%$ \\
\hline Manson (2013) [18] & $44.00 \%$ & $56.00 \%$ \\
\hline
\end{tabular}

\section{TABLE 4: Surgical Rate After Epidural Injection Treatment}

EI = Epidural injection.

\section{Discussion}

We found three different approaches of EI: transforaminal, interlaminar, and caudal. These have been used in the management of sciatica to prevent surgical intervention. Each approach has its own advantage and utility. For instance, the caudal approach has the advantage of avoiding dural puncture, and it can be used in cases where previous surgeries have been done. The advantage of the interlaminar approach includes the ability to treat both unilateral as well as bilateral pain, and it is highly likely that the injected medication will reach adjacent spinal levels [31]. In this review among the 19 studies, the transforaminal approach was observed to be used in 11 studies [1-3, 16-20, 22, 29-30], and thus found to be the most common approach. This may be due to the associated advantage of giving diagnostic information that may indicate the cause of sciatica by blocking the specific root rather than affecting the entire thecal sac [30]. It has been observed that the transforaminal approach is target-specific and reported as the best route to deliver medication to the ventral epidural space and dorsal root ganglion [31]. Additionally, among different approaches, the transforaminal approach requires the smallest volume to reach the primary site of pathology [24].

Further, the transforaminal approach with steroids (triamcinolone, methylprednisolone, betamethasone, and dexamethasone) is found to be a common treatment option for patients with low back pain or sciatica [14, 32]. We observed that particulate steroids [1-2, 17-18, 22-25, 
27-28, 30] such as triamcinolone, methylprednisolone, and betamethasone have been used more commonly in the past ten years than the non-particulate steroids like dexamethasone. However, non-particulate steroids, such as dexamethasone have been suggested as a better option in the literature as they can avoid the potential complication of embolization of particulate steroids, such as Depo-Medrol into the feeder vessels of the spinal cord causing paraplegia [33].

\section{Outcome measures}

The outcome measures assessed in this study are the pain scores, functional disability scores, and the surgical rates after treatment with EI. We assessed whether EIs are capable of preventing surgical intervention or not. We included the studies in which the patients experienced pain for at least two weeks in duration without any relief with the conservative management. Most of these patients were referred for surgical intervention. However, in order to avoid surgical intervention and associated psychological depressive effects, they underwent EI treatment.

A total of 19 studies included in this study, pain scores (Table 2), functional disability scores (Table 3), and subsequent evaluation data were given in 16 and 13 studies, respectively. Both of the outcome measures show significant improvements post-injection.

Surgical rates in the past ten years due to LDH has been reported in 9 studies $[1,16,18-20$, 2425, 29-30], which show a significant reduction in surgical intervention after treatment with EI.

Based on the outcome measures assessment, we have come to the conclusion that an average of greater than $80 \%$ of the patients was successful in preventing surgical intervention after the treatment with EI, which proves our point of preventing surgical intervention with the help of EI treatment in patients suffering from sciatica caused by LDH.

\section{Limitations and future recommendations}

In a recent systematic review by Pountos (2015) et al., [33], several complications such as stroke, damage to the neural element, and death with EI have been reported, but these complications were mostly anecdotal, and actual incidence is unknown. It seems that some individuals may have a high risk of developing complications after receiving EI. Therefore, more research is required to identify those high-risk individuals. In this systematic review, we have not assessed either the short-term or long-term complications of EI with or without steroids. It is due to the fact that most studies failed to report these evaluations. Thus, these evaluations of EIs for the management of sciatica can be done in future studies.

\section{Conclusions}

This study reveals that appropriate use of EI to treat sciatica could significantly improve the pain score and functional disability score, which leads to significant decrease in surgical rate. Additionally, EIs with or without steroids are clinically effective, fast, safe, and a less expensive treatment method as compared to surgical intervention. We concluded that treatment with EI significantly reduces the rate of surgical intervention in patients suffering from chronic sciatica caused by LDH.

\section{Additional Information \\ Disclosures}

Human subjects: All authors have confirmed that this study did not involve human 
participants or tissue. Animal subjects: All authors have confirmed that this study did not involve animal subjects or tissue. Conflicts of interest: In compliance with the ICMJE uniform disclosure form, all authors declare the following: Payment/services info: All authors have declared that no financial support was received from any organization for the submitted work. Financial relationships: All authors have declared that they have no financial relationships at present or within the previous three years with any organizations that might have an interest in the submitted work. Other relationships: All authors have declared that there are no other relationships or activities that could appear to have influenced the submitted work.

\section{References}

1. Kennedy DJ, Plastaras C, Casey E, et al.: Comparative effectiveness of lumbar transforaminal epidural steroid injections with particulate versus nonparticulate corticosteroids for lumbar radicular pain due to intervertebral disc herniation: a prospective, randomized, double-blind trial. Pain Med. 2014, 15:548-555. 10.1111/pme.12325

2. Spijker-Huiges A, Winters JC, van Wijhe M, Groenier K: Steroid injections added to the usual treatment of lumbar radicular syndrome: a pragmatic randomized controlled trial in general practice. BMC Musculoskelet Disord. 2014, 15:341. 10.1186/1471-2474-15-341

3. Ghahreman A, Ferch R, Bogduk N: The efficacy of transforaminal injection of steroids for the treatment of lumbar radicular pain. Pain Med. 2010, 11:1149-1168. 10.1111/j.15264637.2010.00908.x

4. Cook CE, Taylor J, Wright A, Milosavljevic S, Goode A, Whitford M: Risk factors for first time incidence sciatica: a systematic review. Physiother Res Int. 2014, 19:65-78. 10.1002/pri.1572

5. Jacobs WC, Arts MP, van Tulder MW, et al.: Surgical techniques for sciatica due to herniated disc, a systematic review. Eur Spine J. 2012, 21:2232-2251. 10.1007/s00586-012-2422-9

6. Zhai J, Zhang L, Li M, et al.: Epidural injection with or without steroid in managing chronic low-back and lower extremity pain: a meta-analysis of 10 randomized controlled trials. Int J Clin Exp Med. 2015, 8:8304-16.

7. Lee J, Shin JS, Lee YJ, et al.: Effects of Shinbaro pharmacopuncture in sciatic pain patients with lumbar disc herniation: study protocol for a randomized controlled trial. Trials. 2015, 16:455. 10.1186/s13063-015-0993-6

8. Pearson AM, Lurie JD: Surgical versus nonoperative treatment: how do we choose the right approach to lumbar disk herniation?. Pain Manag. 2014, 4:247-249. 10.2217/pmt.14.28

9. Touraine S, Damiano J, Tran O, Laredo JD: Cohort study of lumbar percutaneous chemonucleolysis using ethanol gel in sciatica refractory to conservative treatment. Eur Radiol. 2015, 25:3390-3397. 10.1007/s00330-015-3740-1

10. Jacobs WC, van Tulder M, Arts M, et al.: Surgery versus conservative management of sciatica due to a lumbar herniated disc: a systematic review. Eur Spine J. 2011, 20:513-522.

10.1016/j.spinee.2011.01.010

11. Imagama S, Kawakami N, Tsuji T, et al.: Perioperative complications and adverse events after lumbar spinal surgery: evaluation of 1012 operations at a single center. J Orthop Sci. 2011, 16:510-515. 10.1007/s00776-011-0123-6

12. Manchikanti L, Singh V, Cash KA, Pampati V, Falco F: A randomized, double-blind, activecontrol trial of the effectiveness of lumbar interlaminar epidural injections in disc herniation. Pain Physician. 2014, 17:E61-E74.

13. Kaye AD, Manchikanti L, Abdi S, et al.: Efficacy of epidural injections in managing chronic spinal pain: a best evidence synthesis. Pain Physician. 2015, 18:E939-E1004.

14. Ter Meulen BC, Weinstein H, Ostelo R, Koehler PJ: The epidural treatment of sciatica: its origin and evolution. Eur Neurol. 2016, 75:58-64. 10.1159/000443729

15. Runu R, Sinha NK, Pai R, Shankar PR, Vijayabhaskar P: Our experience with epidural steroid injections in management of low backpain and sciatica. Kathmandu Univ Med J (KUMJ). 2005, 3:349-354.

16. van Helvoirt H, Apeldoorn AT, Ostelo RW, et al.: Transforaminal epidural steroid injections followed by mechanical diagnosis and therapy to prevent surgery for lumbar disc herniation. Pain Med. 2014, 15:1100-1108. 10.1111/pme.12450

17. Manchikanti L, Cash KA, Pampati V, Falco FJ: Transforaminal epidural injections in chronic lumbar disc herniation: a randomized, double-blind, active-control trial. Pain Physician. 2014, 
17:E489-E501.

18. Manson NA, McKeon MD, Abraham EP: Transforaminal epidural steroid injections prevent the need for surgery in patients with sciatica secondary to lumbar disc herniation: a retrospective case series. Can J Surg. 2013, 56:89-96. 10.1503/cjs.014611

19. Kawu AA: Epidural steroid injection in patients with lumbosacral radiculopathy in Abuja, Nigeria. J Neurosci Rural Pract. 2012, 3:121-125. 10.4103/0976-3147.98206

20. Baral BK, Shrestha RR, Shrestha AB, Shrestha CK: Effectiveness of epidural steroid injection for the management of symptomatic herniated lumbar disc. Nepal Med Coll J. 2011, 13:303307.

21. Manchikanti L, Singh V, Cash KA, Pampati V, Damron KS, Boswell MV: A randomized, controlled, double-blind trial of fluoroscopic caudal epidural injections in the treatment of lumbar disc herniation and radiculitis. Spine. 2011, 36:1897-1905. 10.1097/brs.0b013e31823294f2

22. Rados I, Sakic K, Fingler M, Kapural L: Efficacy of interlaminar vs transforaminal epidural steroid injection for the treatment of chronic unilateral radicular pain: prospective, randomized study. Pain Med. 2011, 12:1316-1321. 10.1111/j.1526-4637.2011.01213.x

23. Manchikanti L, Singh V, Falco FJ, Cash KA, Pampati V: Evaluation of the effectiveness of lumbar interlaminar epidural injections in managing chronic pain of lumbar disc herniation or radiculitis: a randomized, double-blind, controlled trial. Pain Physician. 2010, 13:343-355.

24. Laiq N, Khan MN, Iqbal MJ, Khan S: Comparison of epidural steroid injections with conservative management in patients with lumbar radiculopathy. J Coll Physicians Surg Pak. 2009, 19:539-543.

25. Sayegh FE, Kenanidis EI, Papavasiliou KA, Potoupnis ME, Kirkos JM, Kapetanos GA: Efficacy of steroid and nonsteroid caudal epidural injections for low back pain and sciatica: a prospective, randomized, double-blind clinical trial. Spine. 2009, 34:1441-1447. 10.1097/brs.0b013e3181a4804a

26. Manchikanti L, Cash KA, McManus CD, Pampati V, Abdi S: Preliminary results of a randomized, equivalence trial of fluoroscopic caudal epidural injections in managing chronic low back pain: Part 4--Spinal stenosis. Pain Physician. 2008, 11:833-848.

27. Gomez RS, Gusmão S, Silva JF, Bastos MP: Interlaminar epidural corticosteroid injection in the treatment of lumbosciatic pain: a retrospective analysis. Arq Neuropsiquiatr. 2007, 65:1172-1176. 10.1590/s0004-282x2007000700015

28. Owlia M, Salimzadeh A, Alishiri G, Haghighi A: Comparison of two doses of corticosteroid in epidural steroid injection for lumbar radicular pain. Singapore Med J. 2007, 48:241-245.

29. Schaufele MK, Hatch L, Jones W: Interlaminar versus transforaminal epidural injections for the treatment of symptomatic lumbar intervertebral disc herniations. Pain Physician. 2006, 9:361-366.

30. Yang SC, Fu TS, Lai PL, Niu CC, Chen LH, Chen WJ: Transforaminal epidural steroid injection for discectomy candidates: an outcome study with a minimum of two-year follow-up. Chang Gung Med J. 2006, 29:93-99.

31. Cohen SP, Bicket MC, Jamison D, Wilkinson I, Rathmell JP: Epidural steroids: a comprehensive, evidence-based review. Reg Anesth Pain Med. 2013, 38:175-200. 10.1097/aap.0b013e31828ea086

32. Bicket MC, Chakravarthy K, Chang D, Cohen SP: Epidural steroid injections: an updated review on recent trends in safety and complications. Pain Manag. 2015, 5:129-146. 10.2217/pmt.14.53

33. Pountos I, Panteli M, Walters G, Bush D, Giannoudis PV: Safety of epidural corticosteroid injections. Drugs R D. 2016, 16:19-34. 10.1007/s40268-015-0119-3 